\title{
S sciendo
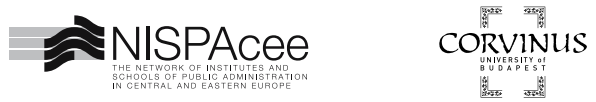

\section{Effectiveness of Public Support for Business Innovation from EU Funds: Case Study in Slovakia}

\author{
Peter Pisár ${ }^{1}$, Ina Ďurčeková ${ }^{1}$ and Milan Křápek ${ }^{2}$
}

\begin{abstract}
Effective public support of innovations, research and development represents one of the priorities of the European Union (EU). The aim of this paper was to examine the effectiveness of one such public programme - public support for business innovation from EU funds in Slovakia - by using selected quasi-experimental design methods on the example of the Operational Programme Competitiveness and Economic Growth for the programming period 2007-2013. The value added of this paper is the fact that we use the method proposed and used by the European Commission and Slovak national authorities. The "difference-in-differences" method is used to compare the changes in value added of supported firms before and after the intervention in comparison to firms that did not receive support. The results suggest that the public support from selected calls of the evaluated operational programme was effective and delivered improvements not only in the field of innovativeness and competitiveness, but also in the area of employment. The evaluated call was much more effective compared to other calls of the programme evaluated by other authors. The responses from the management body suggest that the core success factors were the contents of the call and timing.
\end{abstract}

\section{Keywords:}

Public support for business innovation; EU funds; operational programme competitiveness and Economic Growth.

\section{Introduction}

There is an increasing emphasis put on innovation and innovation performance at the regional, national, as well as international level. Business innovation stim-

1 Faculty of Economics, Matej Bel University in Banska Bystrica, Slovak Republic.

2 AMBIS, a.s. Prague, Czech Republic. 
ulates innovative performance of firms, which in turn helps increase firms' economic growth and competitiveness, which is one of the basic preconditions for a country's competitiveness in an international context. Innovation and innovation performance are therefore important indicators of a country's economic growth. Many experts (e.g. Eggink 2013) agree that the economic entities that generate the largest volume of innovation - the so-called key innovation actors - are business enterprises.

However, firms face various innovation barriers, with one of the main obstacles to developing innovation often being a lack of funding (D’Este et al. 2012). For this reason, firms turn to providers of external funding, such as public support (Spielkamp and Rammer 2009). Businesses use grants, subsidies, tax incentives and other forms of available public support provided by regional, national, or transnational government to develop their innovative activities. The rationale for public support for business innovation is based on both microeconomic and macroeconomic reasons (Arrow 1963; Falk 2007).

The main justification for public support for innovation is the fact that in the absence of public intervention, the private sector would not invest sufficient funds in innovation (Leibowicz 2018). It is therefore not surprising that approximately $1-14 \%$ of total business R\&D expenditure is funded by government (Eurostat 2020). According to OECD (2019), public support for business innovation is used by $14-47 \%$ of innovative businesses in the EU member states, which means that public support is crucial for innovative firms. However, public support does not always have the expected impact and may be spent inefficiently or ineffectively. Although many authors examine the impacts of different types of public support for business innovation, the area of efficiency of public support can generally be considered more explored than the area of effectiveness. For this reason, the paper is focused on the effectiveness of public support provided to business enterprises.

The aim of this paper is to examine the effectiveness of public support for business innovation from EU funds in Slovakia using selected quasi-experimental design methods. The paper aims to contribute to research in the field of public support for business innovation, especially in the context of small and medium enterprises and the ways public support can help these businesses overcome the barriers that hinder the development of innovation.

\section{Literature overview}

Public support for business innovation is the focus of many authors. Several studies argue over the rationale and implications of public support for innovation (e.g. Edquist 1997; Edquist and Borrás 2013; Czarnitzki et al. 2007; Czartinski and Bento 2011; Dodgston and Bessant 1996; Dodgston et al. 2005; Dodgston et al. 2011). When assessing the impacts of public support programmes for innovation, it is nec- 
essary to distinguish between the evaluation of the effectiveness and the efficiency of public support for innovation.

Most studies deal with efficiency (input-output comparisons); the number of studies researching effectiveness is rather limited. Academically published studies by Slovak authors deal mainly with the use of counterfactual methods in evaluating the effectiveness of public support for business innovations. For example, the study by Šipikal, Pisár and Labudová (2013) examines the use of the DiD method for SME support projects. An evaluation study of the effectiveness of business innovation in lagging regions of Slovakia is known by using the production function for the total capital of companies (Némethová et al. 2019), with special emphasis on companies for wood production (Šipikal et al. 2017). The results of a comparative analysis of the impact of business innovation public support in Slovakia and in the EU countries are documented by a study by Pisár et al. (2020). In her dissertation research, Durčeková (2020) dealt with the issue of evaluating the effectiveness of public support for business innovation in Slovakia in a selected programming period. The results of her research are published in co-authorship in this paper. Studies focused on the examination of the impact of public funding on business innovation are frequently published worldwide. There are also published studies of Central European countries, which focus on the problems of implementation of EU funds and evaluation of support for human resources and efficient public administration (e.g. Nyikos and Kondor 2019; Hoffman 2018; Cerar Godec and Benčina 2018). The most frequently used approach in the area of evaluating the impact of public support for innovation and research and development is the use of regression and correlation analysis of panel data at the microeconomic and macroeconomic level. In the international context, several authors (e.g. Marino et al. 2016; Choi and Lee 2017; Hud and Hussinger 2015; Bronzini and Piselli 2009 compare the indicators of supported and non-supported businesses and use specific methods of evaluating efficiency. However, evaluating the effectiveness of public support is a problem area that does not receive sufficient attention, despite the European Commission's emphasis on the need to use counterfactual methods to assess its impact (European Commission 2013).

The evaluation of the effectiveness of public support for business innovation is a specific area that is all the more challenging given that the most significant outputs and results of research and development (R\&D) and innovation investments, such as knowledge and abilities are intangible and immeasurable (Mandl et al. 2008). The authors most commonly use two concepts to evaluate the effectiveness of policy interventions. The first approach is the so-called theory-based impact evaluation (White 2009). The second concept (used in our paper), referred to as "counterfactual impact evaluation" (or "CIE") or "quasi-experimental design", focuses on whether the intervention produced the required changes - the main question that the counterfactual methods answer is "did the intervention bring about change?", which can be further extended to "what change did the intervention bring?" (European Com- 
mission 2013). The aim of counterfactual impact assessment is to identify the net impact or impact of interventions. The most common methods of this evaluation include pairing methods, regression discontinuity, the instrumental variables method and the difference-in-differences (DiD) method (Šipikal and Szitásiová 2020). According to the foreign literature, it is possible to use structural modelling, randomized control trials (RCT- "randomized control trials"), or so-called pipeline methods (Khandker et al. 2009).

The paper uses the difference-in-differences method (also called double difference or DiD) to evaluate effectiveness. This method is based on the assumption that data on trade outputs (e.g. revenues or value added) are available to supported and unsupported firms for the period before and after the intervention. This method evaluates effectiveness by comparing the increase in outputs of supported and non-supported firms. According to Potluka and Špaček (2013), this method should be used to evaluate effectiveness if the data is available for supported and non-supported firms, panel data is available and it is not possible to carry out an experiment. Due to the fulfilment of all these conditions, the difference-in-differences method is used in the paper. The parallel trend assumption must be met in order to use the DiD method. The most commonly used way to verify this assumption is to extend the time dimension of the method with additional data of supported and non-supported firms in the pre-intervention period. In this case, it is possible to graphically represent the average values of the output indicators of supported and non-supported firms for different time periods before the intervention. Where the lines showing the development of supported and unsupported entities appear to be approximately parallel, compliance can be stated assuming parallel development and the results of the method can be interpreted correctly (Wing et al. 2018). The graphical representation of average values of outcome indicators of supported and non-supported firms in the pre-intervention period is used to test this assumption.

The effectiveness of public spending can be influenced by various institutional or structural factors, or by other country-specific elements. These factors are often not under the control of public authorities. However, institutional factors have a key impact on the level of the efficiency and effectiveness of public spending. Various environmental factors (such as the regulatory-competitive framework, the socio-economic background, climatic conditions, economic development or the functioning of public administration) are therefore key to the analysis of efficiency and effectiveness for two reasons. The first is the fact that neglecting these factors can lead to inaccurate measurements of efficiency and effectiveness. The second reason is that these factors may be suitable tools for increasing efficiency and effectiveness (Mandl et al. 2008).

According to Mihau et al. (2010), the effectiveness of public spending is generally influenced by outputs, results and environmental factors. Factors influencing the effectiveness of public support for innovation can be divided from the com- 
pany's point of view into internal and external ones (Albors-Garrigos and Barrera 2011). External factors include environmental factors (such as various socio-economic impacts), the quality and setting of public administration, and corruption, which is strongly linked to environmental factors (Mihau et al. 2010). Herrera and Heijs (2004) include external factors related to the market in which the company operates (e.g. market investment capacity, economic cycle phase, export and import indicators) and technological indicators (e.g. technological cooperation or technology import and export). In general, however, the authors deal mainly with internal factors that relate to company characteristics. For this reason, in our research, emphasis is placed on selected internal factors.

There are few studies examining factors influencing the effectiveness of public support for business innovation. One of these studies, using counterfactual methods of propensity score matching and difference-in-differences, examined the factors influencing the likelihood of a company receiving public support as well as the factors influencing the outcome of a given intervention. These factors included the size of the company (depending on the number of employees and the company's turnover), the company's involvement in research and development activities, industry, ownership (private/state), the region and the age of the company (Department for Business, Energy \& Industrial Strategy 2017). In general, the authors agree that the acquisition of support as well as its effectiveness is influenced mainly by technological intensity and various company characteristics (Albors-Garrigos and Barrera 2011; Radicic et al. 2016; Aboal et al. 2018).

The main company characteristics influencing the effectiveness of public support for business innovation according to available studies are shown in Table 1. Although the use of counterfactual methods to assess effectiveness is not currently a widespread approach, authors examining the effectiveness of public support consider various company characteristics to be key factors. The most frequently examined control variables in the mentioned studies are the size and age of the company, the sector in which the company operates and the involvement of the company in research and development activities. 


\section{Table 1}

Internal factors of effectiveness of public support for business innovation

\begin{tabular}{|l|l|}
\hline \multicolumn{1}{|c|}{ Factor } & \multicolumn{1}{c|}{ Authors } \\
\hline $\begin{array}{l}\text { Size (number of } \\
\text { employees and/or } \\
\text { turnover) }\end{array}$ & $\begin{array}{l}\text { Albors-Garrigos and Barrera (2011), Department for Business, } \\
\text { Energy \& Industrial Strategy (2017), Radicic et al. (2016), Aboal et } \\
\text { al. (2018), Alvarez et al. (2013), Mamede et al. (2015), Czarnitzki et } \\
\text { al. (2011), Reinkowski et al. (2011) }\end{array}$ \\
\hline Industry & $\begin{array}{l}\text { Radicic et al. (2016), Department for Business, Energy \& Industrial } \\
\text { Strategy (2017), Czarnitzki et al. (2011), Mamede et al. (2015) }\end{array}$ \\
\hline Age & $\begin{array}{l}\text { Alvarez et al. (2013), Mamede et al. (2015), Reinkowski et al. } \\
\text { (2011), Aboal et al. (2018), Department for Business, Energy \& } \\
\text { Industrial Strategy (2017), }\end{array}$ \\
\hline R\&D activities & $\begin{array}{l}\text { Albors-Garrigos and Barrera (2011), Department for Business, } \\
\text { Energy \& Industrial Strategy (2017), Aboal et al. (2018) }\end{array}$ \\
\hline Region & $\begin{array}{l}\text { Department for Business, Energy \& Industrial Strategy (2017), } \\
\text { Radicic et al. (2016) }\end{array}$ \\
\hline Ownership & Department for Business, Energy \& Industrial Strategy (2017) \\
\hline Part of a group & $\begin{array}{l}\text { Aboal et al. (2018), Department for Business, Energy \& Industrial } \\
\text { Strategy (2017), Czarnitzki et al. (2011) }\end{array}$ \\
\hline Export & Radicic et al. (2016), Aboal et al. (2018), Czarnitzki et al. (2011) \\
\hline $\begin{array}{l}\text { Type of innovation } \\
\text { activity }\end{array}$ & Aboal et al. (2018), Radicic et al. (2016) \\
\hline
\end{tabular}

Source: Authors

There are only few studies focused on the effectiveness of public support for business innovation from the EU funds using counterfactual impact evaluation. Bondonio et al. (2015) focused on the sample of Italian firms supported from the programmes funded by EFRD, using the difference-in-differences method in combination with propensity score matching and concluded that subsidies did not stimulate additional private innovation investment in big firms, but were effective to a certain extent in smaller firms. Dvouletý and Blažková (2019) researched public support from EFRD in the Czech Republic and, using counterfactual impact evaluation, found that subsidies from the operational programme under review had a positive impact on the performance of supported firms.

However, several studies regarding the public support for business innovation using CIE methods were conducted by the Slovak Government (Government Office of the Slovak Republic 2015; Ministry of Economy of the Slovak Republic 2014). The effectiveness evaluation was first used in the programming period 2007-2013, when counterfactual methods were used in the strategic evaluation of the Operational Programme Competitiveness and Economic Growth (Ministry of Economy of the Slovak Republic 2014). The Ministry of Economy highlights this type of evaluation as one of the key tools for estimating quantitative changes within the OP, which should contribute to the disclosure of causal relationships, effects and inter- 
ventions. The counterfactual impact assessment was also used by the Government Office of the Slovak Republic (2015), which published results based on the use of difference-in-differences and propensity score matching methods in combination with regression analysis. The research analyzed the effectiveness of interventions on the basis of three indicators, while the effectiveness was evaluated positively only on the basis of the increase in added value of supported and non-supported subjects (in the case of other indicators, the impact of the intervention was zero or negative). The only well-known publication is the research by Lešková and Nemethová (2016), which examined the effectiveness of the Operational Programme Competitiveness and Economic Growth in the programming period 2007-2013 on the basis of the difference-in-differences method on a smaller sample of supported and unsupported enterprises. The authors concluded that public support for innovation from EU funds was spent ineffectively in this case.

\section{Methodology}

The object of our research about the effectiveness of the support for business innovation from the EU structural funds is the last completed programming period 2007-2013. In the given programming period, public support for business innovation from EU structural funds was redistributed through non-repayable financial contribution (NFC). Based on data from the Ministry of Economy of the Slovak Republic and the Slovak Innovation and Energy Agency (SIEA), sub-measure 1.1.1. (Supporting the take-up of innovation and technology transfers and related challenges to support business innovation) was chosen for further analysis. The analysis is based on data from three sources, namely from the requested database provided by the Ministry of Economy of the Slovak Republic on supported and non-supported projects, from the Finstat database and from the public financial statements of supported and non-supported companies. The evaluation of effectiveness is carried out on a sample of supported and non-supported firms and covers two calls - call CaEG-111DM-1301 and call CaEG-111SP-1201. The calls were chosen on the basis that the necessary data are not available for older calls. The evaluation is applied to two calls due to the inclusion of both types of schemes used - state aid scheme and de minimis aid scheme. Based on the article and the acquired knowledge of the studied subject, we define the research questions as follows:

$\mathrm{R} 1$ : What is the effectiveness of public support for business innovation from Operational Programme Competitiveness and Economic Growth in programming period 2007-2013 in Slovakia?

R2: In which types of businesses does provided public support achieve the highest effectiveness?

The research methodology was based on a combination of deduction methods, induction, comparisons and synthesis. Effectiveness is measured by comparing 
the data on value added of supported and non-supported firms before and after intervention (the call) using the difference-in-differences method. We use data on value added 2 years before and 2 years after the call to include changes in firms' outcomes over longer period of time before and after the intervention. Firms with an extreme increase/decrease in value added over the monitored period were excluded from the analysis in order to provide the most eligible results. The statistical significance of the difference between supported and non-supported firms is examined through the use of the nonparametric Mann-Whitney test. The suitability of the difference-in-differences approach is verified using a parallel trend in the pre-intervention period assumption test.

In order to compare the level of effectiveness of public support, the $\mathrm{DiD}$ method is applied to different groups of firms based on their size, age and region, based on which we evaluate in which group of firms the highest effectiveness of public support is achieved. In order to examine the benefits of public support from the EU funds, factors influencing the growth of outcome indicators of supported firms (e.g. the amount of provided funds or co-financing) are analyzed employing linear regression analysis using the least squares method. In the research, we did not have certain data available for supported and unsupported enterprises (e.g. data on the number of newly created jobs), so the evaluation focused only on selected indicators of corporate production (increase in sales and value added).

Our evaluation in research also had certain strengths and weaknesses. In the research, we did not have certain data available for supported and non-supported enterprises (e.g. data on the number of newly created jobs), so the evaluation focused only on selected indicators of enterprise output (increase in sales and value added). The research focused on selected challenges due to the availability of data. The advantage of a survey in comparison with other evaluations was the finding that there was a relatively high number of applicants for support, which represented a large sample of companies, compared to the domestic study by Lešková and Némethová (2016). Using the DiD method, the result of the positive effectiveness of the provided support was quantified.

\section{Effectiveness of public support for business innovation from OP Competitiveness and Economic Growth in the programming period 2007-2013 in Slovakia}

Even though business innovation is supported by all levels of government, EU funds are especially important when it comes to supporting business innovation in the EU. According to the Community Innovation Survey 2014 (Eurostat 2017), EU funds are the main public resource used to support business innovation activities in most EU countries, especially those lagging behind the EU average in terms of innovation performance. This statement is also supported available statistical data 
at national level, which shows that $\mathrm{EU}$ funding has been the main source of public support for business innovation in Slovakia since 2006 (Figure 1). The share of innovative firms using the EU funds to launch innovation projects usually decreases in the beginning of the programming period (years 2008 and 2014) when the calls are announced and increases later in the programming period when the funds from the operational programmes are allocated.

\section{Figure 1}

Share of innovative enterprises that received public support according to the source of funding

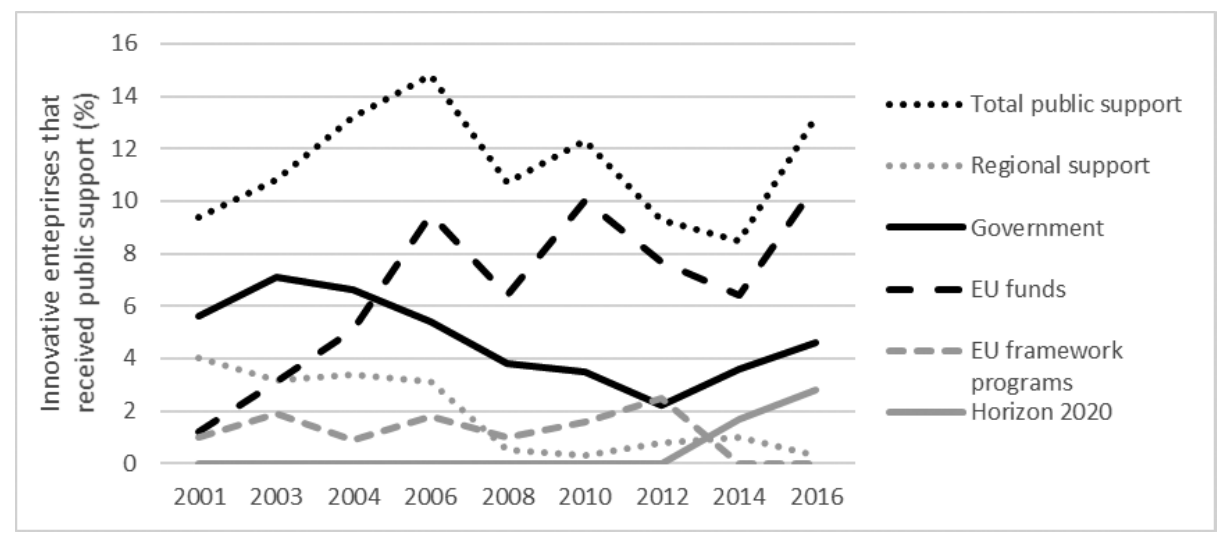

Source: Authors

Based on these findings the paper is focused on analyzing the public support from the EU structural funds allocated in Slovakia in the programming period 2007-2013 from Operational Programme Competetiveness and Economic Growth - more specifically submeasure 1.1.1. Within this submeasure 779 projects were supported and 1,523 submissions were rejected. The data in the tables inform about the structure of supported and unsupported projects in terms of various aspects, such as, e.g., the region and sector in which the entity operated, the type of scheme from which the entity applied for support, the duration of the project, etc.

We can observe that the support was relatively evenly distributed between all three regions. The most supported projects were in Western Slovakia, where the most entities applied for support. We consider these results to be surprising, as in the Western Slovakian region, according to the KaHR Programme Manual, the aid intensity was the lowest, which means that entities in this region were entitled to a non-repayable financial contribution lower than their eligible expenses in other regions. It should be noted that entities operating in the Bratislava region could not be supported from the operational programme. 


\section{Table 2}

Supported and non-supported projects in terms of the region in which the entity operates

\begin{tabular}{|l|c|c|c|}
\hline \multicolumn{1}{|c|}{ Region } & Supported projects & $\begin{array}{c}\text { Non-supported } \\
\text { projects }\end{array}$ & Total \\
\hline Western Slovakia & $275(35.3 \%)$ & $516(33.9 \%)$ & $791(34.4 \%)$ \\
\hline Middle Slovakia & $231(29.7 \%)$ & $529(34.7 \%)$ & $760(33.0 \%)$ \\
\hline Eastern Slovakia & $273(35.0 \%)$ & $478(31.4 \%)$ & $751(32.6 \%)$ \\
\hline Total & 779 & 1,523 & 2,302 \\
\hline
\end{tabular}

Source: Authors

Table 3

Supported and non-supported projects from the perspective of the open calls

\begin{tabular}{|l|l|l|l|}
\hline \multicolumn{1}{|c|}{ Open calls } & $\begin{array}{c}\text { Supported } \\
\text { projects }\end{array}$ & $\begin{array}{c}\text { Non-supported } \\
\text { projects }\end{array}$ & Total \\
\hline State aid calls & & & \\
- 111SP-0801 & 22 & 277 & 299 \\
- 111SP-0902 & 69 & 89 & 158 \\
- 111SP-1001 & 36 & 114 & 150 \\
- 111SP-1101 & 51 & 275 & 326 \\
State aid total & 156 & 142 & 298 \\
\hline Calls de minimis & $\mathbf{3 3 4}$ & $\mathbf{8 9 7}$ & $\mathbf{1 , 2 3 1}$ \\
scheme & & & \\
- 111DM-0801 & 64 & 131 & 195 \\
- 111DM-0901 & 65 & 90 & 155 \\
- 111DM-1301 & 316 & 405 & $\mathbf{7 2 1}$ \\
De minimis total & $\mathbf{4 4 5}$ & $\mathbf{6 2 6}$ & $\mathbf{1 , 0 7 1}$ \\
\hline
\end{tabular}

Source: Authors

In terms of the type of scheme (Table 3), more entities applied for state aid calls than for de minimis aid. However, this was mainly due to the fact that more than one de minimis call was issued for state aid calls. More applicants were supported under de minimis support schemes, while most applicants, supported and unsupported projects, can be observed in scheme 111DM-1301.

Based on the data from the Ministry of Economy Table 4 shows selected critical outcome indicators of firms supported within the sub-measure 1.1.1. of Operational Programme Competetiveness and Economic Growth. 


\section{Table 4}

Outcome indicators of supported entities by region in Slovakia

\begin{tabular}{|l|c|c|c|c|}
\hline \multicolumn{1}{|c|}{ Indicator } & $\begin{array}{c}\text { Western } \\
\text { Slovakia }\end{array}$ & $\begin{array}{c}\text { Middle } \\
\text { Slovakia }\end{array}$ & $\begin{array}{c}\text { Eastern } \\
\text { Slovakia }\end{array}$ & Total \\
\hline Revenue growth $(\boldsymbol{\epsilon})$ & $5,839,503$ & $4,579,042$ & $5,313,604$ & $5,082,971$ \\
\hline Value added growth $(\epsilon)$ & $1,749,725$ & $1,426,406$ & $1,551,141$ & $1,577,531$ \\
\hline Number of created jobs & 5.80 & 4.54 & 6.34 & 5.52 \\
\hline $\begin{array}{l}\text { Number of innovated } \\
\text { production processes }\end{array}$ & 2.34 & 2.36 & 2.65 & 2.44 \\
\hline
\end{tabular}

Source: Authors

The results show that the public support has contributed to value creation in all areas. Revenues of supported firms increased on average by more than 5 million EUR, value added increased on average by more than $1.5 \mathrm{mil}$. and, on average, 5.52 jobs were created and 2.44 production processes were innovated as a result of the public support beneficiaries received. In the case of revenues and value added, the highest increase in the observed indicators was achieved by firms operating in Western Slovakia. However, in terms of indicators focused on employment and innovation itself, Eastern Slovakia showed the best results. We consider the high average increase in newly created jobs in the Eastern Slovak region to be one of the most significant quantifiable benefits of public support for innovation in this region.

Our research shows that the support from the selected calls was mostly focused on SMEs younger than 20 years that operated in the field of manufacturing (in line with the focus of the operational programme). The applied difference-in-differences method to analyze the impact of provided public support delivers positive results (Table 5).

Table 5 shows that value added grew in both supported and non-supported firms in both periods, before and after the intervention. However, we can see that in the firms that received the financial resources, value added grew faster in the period after intervention, while the opposite happened with non-supported firms. Based on the analysis, we can conclude that value added grew faster by 54 percentage points in supported firms. The results were statistically verified using the Mann-Whitney test, which showed that there is a statistically significant difference between supported and non-supported firms. The model was also verified by testing the parallel trend assumption of supported and non-supported firms in the pre-intervention period (see Figure 2), which shows that the average value added of firms that received the support and the firms whose requests were rejected has a similar trend before the call, meaning that the difference between the value added of supported and non-supported firms can be explained as the impact of the intervention. 


\section{Table 5}

Results of the difference-in-differences method using value added of supported and non-supported firms on a sample of two calls from OP CaEG

\begin{tabular}{|c|c|c|c|}
\hline & \multicolumn{2}{|c|}{ Change in value added } & \multirow{2}{*}{$\begin{array}{l}\text { Difference } \\
\text { between periods }\end{array}$} \\
\hline & $\begin{array}{c}\text { Before } \\
\text { intervention }\end{array}$ & After intervention & \\
\hline Supported firms & $51 \%$ & $68 \%$ & 17 p.p. \\
\hline Non-supported firms & $86 \%$ & $49 \%$ & -37 p.p. \\
\hline $\begin{array}{l}\text { Difference between } \\
\text { supported and non- } \\
\text { supported firms }\end{array}$ & -35 p.p. & 19 p.p. & $\begin{array}{c}\text { 54\% p.p. } \\
(332+279) \\
{[-2.899 * * *]}\end{array}$ \\
\hline
\end{tabular}

Note: (.) values show number of supported + non-supported firms included in the analysis; [.] values show $\mathrm{z}$-statistic of Mann-Whitney test and ${ }^{*} /{ }^{* * * *}$ show statistical significance on the $10 \% / 5 \% / 1 \%$ significance level.

Source: Authors

\section{Figure 2}

Graphic representation of the parallel trend assumption

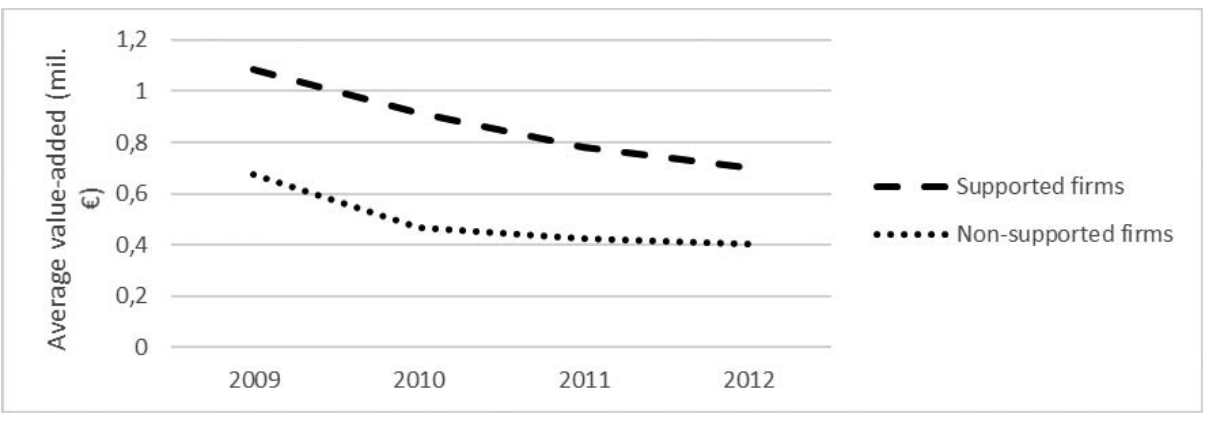

Source: Authors

Based on the results and the applied tests, we can state that the public support from the selected calls was effective. However, we maintain that it is not only important to evaluate the effectiveness of the public support as a whole, but to also examine which groups of firms achieve the highest effectiveness of the provided support and should thus be the main focus of the public support in the future. 


\section{Which businesses achieve the highest effectiveness of public support?}

The effectiveness of public support measured by the difference-in-differences method on our sample of supported and non-supported firms significantly differs by three selected characteristics, region, size and age (Table 6).

Table 6

Results of the difference-in-differences method based on the region, age and size of a firm

\begin{tabular}{|l|c|c|c|c|c|}
\hline \multicolumn{2}{|c|}{ Region } & \multicolumn{2}{c|}{ Size } & \multicolumn{2}{c|}{ Age } \\
\hline Middle Slovakia & +109 & Micro & +24 & $0-10$ years & +88 \\
\hline Eastern Slovakia & -12 & Small & +101 & $10-20$ years & +61 \\
\hline Western Slovakia & +87 & Medium & +108 & Over 20 years & -65 \\
\hline
\end{tabular}

Note: values show increase (+) or decrease (-) of value added in percentage points of supported firms compared to non-supported firms in the period after the intervention compared to the pre-intervention period; bold values show results that were significant based on the parallel trend assumption test.

Source: Authors

However, not all results of the DiD method are appropriate for interpretation since some samples did not meet the parallel trend assumption. The results show that the support had the desired impact in Middle and Western Slovakia, while support provided to firms in Eastern Slovakia was not effective since the value added (before vs. after intervention) grew faster in the firms that did not receive support. However, the parallel trend assumption was not met in this region, so we cannot confirm this result. The results concerning the size and the age of the firm are especially interesting. Based on our findings, the impact was higher in the bigger firms (although in small and medium firms, the parallel trend assumption was not met). Large firms were not included in the analysis based on the small sample size. The findings related to the age of the firm show that the impact of the support was higher in younger firms, while in firms over the age of 20 , the impact was negative.

Research examining the impact of factors in the effectiveness of public support for innovation has focused on selected challenges due to the availability of data. When examining the factors influencing the changes of the four examined indicators for the supported projects under sub-measure 1.1.1., we create two alternative groups of models. The first group of models uses only data from the Ministry of Economy, it examines the supported projects of all entities (corporate/individual), but does not include the impact of company characteristics. The second group of models focuses only on supported projects of legal entities and also includes 
company characteristics, about which we obtained information from the Finstat database. In both cases, we use four different dependent variables: an increase in sales (in euros), an increase in value added (in euros), the number of new jobs created and the number of innovated production processes. We also created several regression models aimed at examining if selected characteristics related to receiving public support had an impact on outcome indicators of selected firms. The models examined the impact of type of entity $(1$ - corporate entity, 0 - individual), amount of provided funds (EUR), level of co-financing (\% of provided funds) and length of project duration (years). Table 7 shows results of linear regression models of these variables on outcome indicators of supported firms from sub-measure 1.1.1 in various Slovak regions.

\section{Table 7}

Results of regression models examining the impact of firm characteristics on outcome indicators of supported firms

\begin{tabular}{|c|c|c|c|c|}
\hline & $\begin{array}{l}\text { Value added } \\
\text { growth }\end{array}$ & $\begin{array}{l}\text { Revenue } \\
\text { growth }\end{array}$ & $\begin{array}{l}\text { Number of } \\
\text { innovated } \\
\text { innovation } \\
\text { processes }\end{array}$ & $\begin{array}{l}\text { Number of } \\
\text { created jobs }\end{array}$ \\
\hline Constant & $\begin{array}{c}-1,580,263 * * * \\
(-3.4770)\end{array}$ & $\begin{array}{c}-5,488,627 * * * \\
(-3.5422)\end{array}$ & $\begin{array}{c}1.9699 * * * \\
(2.9134)\end{array}$ & $\begin{array}{c}-0.9304 \\
(-0.7441)\end{array}$ \\
\hline Type of entity & $\begin{array}{c}1,156,043 * * * \\
(4.2187)\end{array}$ & $\begin{array}{c}3,918,981^{* * *} \\
(4.1948)\end{array}$ & $\begin{array}{c}-0.566 \\
(-1.3586)\end{array}$ & $\begin{array}{c}1.1138 \\
(1.4622)\end{array}$ \\
\hline Provided funds & $\begin{array}{c}0.6452 * * * \\
(5.8704)\end{array}$ & $\begin{array}{c}2.1264 * * * \\
(5.6748)\end{array}$ & $\begin{array}{l}7.6 \mathrm{E}-08 \\
(0.4465)\end{array}$ & $\begin{array}{c}\text { 5.77E-06*** } \\
(18.9999)\end{array}$ \\
\hline Co-financing & $\begin{array}{c}31,547 * * * \\
(3.4071)\end{array}$ & $\begin{array}{c}106,958 * * * \\
(3.3882)\end{array}$ & $\begin{array}{c}0.0075 \\
(0.5192)\end{array}$ & $\begin{array}{l}0.0635 * * \\
(2.4766)\end{array}$ \\
\hline Project duration & $\begin{array}{c}447,168.6 * * * \\
(2.5977) \\
\end{array}$ & $\begin{array}{c}1,380,020 \\
(2.3514) \\
\end{array}$ & $\begin{array}{c}0.7886 * * * \\
(2.9349) \\
\end{array}$ & $\begin{array}{c}-0.4536 \\
(-0.9518) \\
\end{array}$ \\
\hline $\begin{array}{l}\mathrm{R}^{2} \text { adjusted } \\
\text { Observations } \\
\text { F-statistic } \\
\text { Akaike } \\
\text { information } \\
\text { coefficient }\end{array}$ & $\begin{array}{c}0.1314 \\
779 \\
30.4126 * * * \\
32.2028\end{array}$ & $\begin{array}{c}0.1241 \\
779 \\
28.5474 * * * \\
34.6259\end{array}$ & $\begin{array}{c}0.0165 \\
694 \\
3.8999 * * * \\
5.2864\end{array}$ & $\begin{array}{c}0.3682 \\
776 \\
112.3666 * * * \\
6.5742\end{array}$ \\
\hline
\end{tabular}

Note: (.) values show t-statistics, ${ }^{*} / * / * * *$ shows statistical significance at $10 \% / 5 \% / 1 \%$ significance level. 85 projects were excluded from the analysis in the "number of innovated innovation processes" model and 3 projects were excluded in the "number of created jobs" models due to unavailability of data.

Source: Authors

All models appear to be statistically significant at all common levels of significance based on F-statistics and associated p-values. However, we can see the differences in the adjusted coefficients of determination - while in the case of value 
added and revenues the coefficient of determination was adjusted to a level lower than 0.14 , in the model focused on newly created jobs the coefficient was higher. We do not consider the lower values of the coefficient of determination in the case of models examining the increase in revenues and value added to be surprising, as revenues and value added of the firm are affected by many internal and external factors that do not relate to obtaining support (e.g. demand, production costs, market competition, etc.). However, in the case of the model examining the impact on the number of innovated production processes, the adjusted coefficient of determination was very low. In this model, it was also not possible to confirm the statistical significance of the impact of the monitored independent variables (except for the project duration) on the number of innovated processes. Given that the number of innovated processes is a direct output of the introduction of innovations (unlike other monitored output indicators), we consider these results to be surprising, as we assumed that the level of support received will affect innovation in the company. This model was estimated as the optimal in terms of the Akaike information criterion (due to the lowest value of AIC), but due to the low coefficient of determination and statistical insignificance of the indicators, we consider it unsuitable for economic interpretation.

The type of entity (i.e. whether the supported project was carried out by an individual or a corporate entity) was statistically significant only in the case of models examining the impact of variables on the increase in value added and the increase in sales. These results correspond to previous findings, according to which corporate entities achieved on average a higher increase in value added and revenues, while in terms of job creation, self-employed persons had better results. The duration of the project was statistically significant in the case of an increase in added value and the number of innovated production processes. In both cases, the duration of the project had a positive effect, which means that if the project lasted longer, the companies achieved a higher increase in the monitored indicators. This result is probably related to the fact that in the case of a longer-lasting project, the company had more time to generate the monitored outputs (i.e. the increase in the indicator was monitored over a longer period of time). The level of co-financing was statistically significant for all models except innovated processes. We consider it interesting that the level of co-financing had a positive effect on changes in output indicators, which means that the more the entity participated in co-financing the project from its own funds, the higher the increase in output indicators. We assumed that the level of co-financing would have a negative impact on the monitored indicators, as in the case of lower co-financing the company had more internal funds available to expand its business and could invest more funding in achieving higher outputs. However, it seems that a higher level of co-financing has a positive effect on the generation of outputs, so the level of co-financing is unlikely to be an obstacle to the use of public support by firms. From our point of view, the most significant independent variable examined is the amount of provided funds (i.e. the volume of subsidy). This variable, like the 
level of co-financing, was statistically significant in all models except the model focused on innovative production processes. The amount of provided funds had a positive effect on revenue growth, added value growth, as well as on the number of created jobs of supported firms. The results show that an increase in the provided grants by 1 EUR resulted on average in:

- an increase in value added by 0.65 EUR,

- an increase in sales by $2.13 \mathrm{EUR}$,

- an increase in the number of newly created jobs by 0.000006 jobs (we can say that with the increase of the subsidy by 1 million EUR, we could expect on average an increase in jobs created by less than 6 jobs).

\section{Conslusions}

The type of entity (i.e. whether the supported project was carried out by an individual or a corporate entity) was statistically significant only in the case of models examining the impact of variables on the increase in value added and the increase in sales. These results correspond to previous findings, according to which corporate entities achieved on average a higher increase in value added and revenues, while in terms of job creation, self-employed persons had better results.

Our results confirm the positive impact of the amount of financial resources provided from sub-measure 1.1.1 aimed at supporting innovation in firms on the increase of output indicators of supported firms - effectiveness of this public programme. According to our results, the level of public support is the most critical factor delivering an increase of the competitiveness of firms (in the form of increasing revenues and added value), but also in creating jobs and increasing employment of Slovak regions. By this the key conclusion of the paper is that value added in supported firms grew faster than in firms that did not receive funding from the operational programme. On this basis, we can say that businesses that launched innovation projects as a result of obtaining support from the EU funds have increased their competitiveness to a certain extent. Given that the increase of supported firms' competitiveness is one of the objectives of the Operational Programme Competitiveness and Economic Growth, based on our results, we can state that this goal was met.

Not only did value added grow faster in the supported firms, public support also led to the creation of new jobs and an increase of other outcome indicators. Creating new jobs and innovating production processes in the firms is among the main goals of supported projects. Projects supported under sub-measure 1.1.1. contributed to the innovation of 1,691 production processes and to the creation of 4,283 jobs in the supported firms. Of this, almost 1,500 jobs were created in Eastern Slovakia, where we have been facing high unemployment for a long time. Therefore, we can state the benefits of support from the Operational Programme 
Competitiveness and Economic Growth not only in the development of business competitiveness, but also in overcoming economic and social disparities between the regions of Slovakia.

Such really positive results are a bit surprising, because other similar evaluations are much less positive (especially Lešková and Némethová 2016). To try to establish factors of success we interviewed a top administrator from the implementation agency. His response is interesting: "I feel that the explanation is very prosaic - your research evaluated one of the last calls with a really high level of interest - the number of submitted proposals. The higher level of competition and the transparent selection process directed the public support to the best applicants. Moreover, both calls were very simple from the point of their focus - they covered purchases of new technologies."

Our research also shows that the effectiveness of provided funds was highest in the youngest firms, and in firms that have been established over 20 years ago, the impact was negative. We believe that these conclusions stem from the market position of younger and older firms. Firms that have been operating on the market for a longer period of time can be considered more economically stable. These firms have had a longer time to build a market position and obtain sufficient financial and administrative resources needed to handle innovative projects on their own. Therefore, we assume that not being able to qualify for public support for a firm that has been operating on the market for a longer period of time does not have the same consequences as if it were a younger company. Younger businesses often do not have a sufficient amount of their own resources, which makes the public support crucial for them.

We are aware that there are several weaknesses of the evaluation of effectiveness presented in the paper, e.g. the fact that we did not have certain data available for supported and non-supported enterprises (e.g. data on the number of newly created jobs), so the evaluation focused only on selected indicator of enterprise output (increase in value added). Also, the analysis focused only on selected calls due to the availability of data. However, we feel that these limits do not impact the findings on a significant scale.

There are also certain barriers connected with using the counterfactual impact evaluation in the conditions of Slovakia and other EU countries. In our case the outcome indicators used in the paper are most commonly used to monitor and evaluate public support from the EU funds. Two questions arise in this connection - whether these indicators provide a sufficient basis for assessing the effectiveness of the public support and whether the indicators are reported correctly. The first question is addressed in the evaluation report of the Government Office of the Slovak Republic (2015), which states that the currently used indicators could be more informative if additional indicators were used that would indicate not only the effectiveness but also the efficiency and productivity of support. According to this 
publication, it would be appropriate to consider the inclusion of other indicators, such as labour productivity or capital productivity. At present, we encounter the most frequent use of value added and revenue indicators due to the relatively simple availability of data on these indicators, which means that especially in academia, these evaluations can be carried out on the basis of publicly available data. However, the inclusion of other indicators that would provide a more comprehensive view of the firm's impact would certainly be beneficial in terms of assessing the effectiveness of interventions.

It is also possible to argue about whether the data used by the Ministry of Economy reflect the real state of supported firms. Data on output indicators used in the official evaluation of the Operational Programme Competitiveness and Economic Growth and the Operational Programme Research \& Development are obtained from the central information system ITMS, where the data are entered by the applicants and beneficiaries themselves. Applicants declare the baseline and planned values of measurable indicators, but it is not clear from the available documents whether the data reported by the applicants are verified in any way. As a result, the results of the effectiveness evaluation may be skewed when using the indicators obtained from the ITMS. Based on these findings, we believe that it is most appropriate to perform the efficiency analysis on the basis of publicly available data and use the data from project monitoring only as an additional source of data, as was the case in the translated dissertation.

The policy recommendation delivered by our paper is obvious - we propose to use counterfactual methods in assessing the effectiveness of public support for business innovation as one of the critical evaluation tools, because we believe that these methods are key to analyzing the impact of support on competitiveness, employment and innovation performance, which helps policy makers assess its benefits. However, it is necessary to remember that these methods have certain limitations and their application must use data that are correctly reported and collected to achieve correct results and conclusions.

\section{Acknowledgement}

This work was supported by the Slovak Research and Development Agency under the contract No. APVV-15-0322.

\section{References}

Aboal, Diego et al. 2018. "How Effective and Innovation Support Programs to Stimulate Innovation? Evidence grom Paraguay." Documentos de Trabajo LACEA 017233. Available at https://www.bcu.gub.uy/Comunicaciones/Jornadas\%20 de\%20Economa/Diego_Aboal.pdf (last accessed 4. April 2021). 
Albors-Garrigos, Jose and Rosa Rodrigues Barrera. 2011. "Impact of Public Funding on a Firm's Innovation Performance: Analysis of Internal and External Moderating Factors." International Journal of Innovation Management 15(6), $1297-1322$.

Alvarez, Roberto, Bravo, Claudio and Zahler, Andrés. 2013. "Impact Evaluation of Innovation Programs in the Chilean Services Sector." Documento de trabajo/Working Paper No 2013 (SS-IP)-02. Available at http://www.cinve.org.uy/ wp-content/uploads/2013/10/DT-N\%C2\%B0-2013_SS-IP_-02-Zahler-UDiego-Portales.pdf (last accessed 4. April 2021).

Arrow, Kenneth J. 1962. "Economic Welfare and the Allocation of Resources for Invention." Princeton University Press: 219-236.

Bondonio, Danielle et al. 2015. "Counterfactual Impact Evaluation of Enterprise Support Programmes: Evidence from a Decade of Subsidies to Italian Firm." ERSA conference papers, European Regional Science Association. Available at https://ideas.repec.org/p/wiw/wiwrsa/ersa15p1619.html (last accessed 4. April 2021).

Bronzini, Rafaello and Paolo Piselli. 2009. "Determinants of Long-Run Regional Productivity with Geographic Spillovers: The Role of R\&D, Human Capital and Public Infrastructure." Regional Science and Urban Economics 2(39), 187-199.

Cerar Godec, Lucia and Jože Benčina. 2018. "Impact of Active Labour Market Policy Programs on Employment in the EU During the Crisis." Central European Public Administration Review 16(1), 31-50.

Choi, Joonwhan and Jaegul Lee. 2017. "Repairing the R\&D Market Failure: Public R\&D Subsidy and the Composition of Private R\&D." Research Policy 46(8), 1465-1478.

Czarnitzki, Dirk and Cindy Lopes Bento. 2011. "Counterfactual Impact Evaluation of Cohesion Policy: Examples from Support to Innovation and Research." Katholieke Universiteit Leuven Work package 2 Final Report. Available at https://ec.europa.eu/regional_policy/sources/information/evaluations/pdf/ impact/ciewp2_final.pdf (last accessed DATE).

Czarnitzki, Dirk, Bernd Ebersberger and Andreas Fier. 2007. "The Relationship between R\&D Collaboration, Subsidies and R\&D Performance: Empirical Evidence from Finland and Germany." Journal of Applied Econometrics 22(7), 1347-1366.

Czarnitzki, Dirk, Petr Hanel and Julio Miguel Rosa. 2011. "Evaluating the Impact of R\&D Tax Credits on Innovation: A Microeconomic Study on Canadian Firms." Research Policy 20(2), 217-229. 
Department for Business, Energy \& Industrial Strategy. 2017. “The Impact of Public Support for Innovation on Firm Outcomes." Available at https://www.gov.uk/ government/uploads/system/uploads/attachment_data/file/604841/innovation-public-support-impact-report-2017.pdf (last accessed 4. April 2021).

D’Este, Pablo et al. 2012. "What Hampers Innovation? Revealed Barriers versus Deterring Barriers." Research Policy 41(2), 483-488.

Dodgston, Mark and John Bessant. 1996. Effective Innovation Policy: A New Approach. London: International Thomson Business Press.

Dodgston, Mark, D. Gann and A. Satter. 2005. Think, Play, Do: Technology, Innovation and Organization. London: Oxford University Press.

Dodgston, Mark et al. 2011. "System Thinking, Market Failure, and the Development of Innovation Policy: The Case of Australia." Reserach Policy 40(9), $1145-1156$.

Ďurčeková, Ina. 2020. Verejná podpora podnikových inovácií a jej účinnost. Dizertačná práca. Banská Bystrica: Ekonomická fakulta UMB v Banskej Bystrici.

Dvouletý, Ondřej and Ivana Blažkov. 2019. "Assessing the Microeconomic Effect of Public Subsidies on the Performance of Firms in the Czech Food Processing Industry: A Counterfactual Impact Evaluation." Agribusiness 35(3), 394-422.

Edquist, Charles. 1997. Systems of Innovation: Technologies, Institutions and Organizations. London: Pinter.

Edquist, Charles and Susana Borrás. 2013. "The Choice of Innovation Policy Instruments." Technological Forecasting and Social Change 80(8), 1513-1522.

Eggink, Maria. 2013. "The Components of Innovation System: A Conceptual Innovation System Framework." Journal of Innovation and Business Best Practices $1,1-12$.

European Commission. 2013. Design and Commissioning of Counterfactual Impact Evaluations. Luxembourg: Publications Office of the European Union.

Eurostat. 2017. Community Innovation Survey 2014. Available at https://ec.europa. eu/eurostat/web/products-eurostat-news/-/DDN-20170124-2 (last accessed 4. April 2021).

Eurostat. 2020. "R\&D Expenditure: Eurostat Statistics Explained." Available at https:// ec.europa.eu/eurostat/statistics-explained/index.php?title=R_\%26_D_expenditure (last accessed 4. April 2021).

Falk, Rahel. 2007. "Measuring the Effects of Public Support Schemes on Firms' Innovation Activities: Survey Evidence from Austria." Research Policy 36(5), $665-679$. 
Government Office of the Slovak Republic. 2015. Hodnotenie vybraných intervencií ŠF a KF využitím metód Counterfactual Impact Evaluation. Záverečná správa. Úrad vlády SR. Centrálny koordinačný orgán. Available at http://www.nsrr. sk/download.php?FNAME=1444742081.upl\&ANAME=Hodnotenie $+v y-$ bran\%C3\%BDch+intervenci\%C3\% AD+\%C5\%A0F+a+KF+vyu\%C5\%BEit $\%$ C $3 \% \mathrm{ADm}+$ met $\% \mathrm{C} 3 \% \mathrm{~B} 3 \mathrm{~d}+\mathrm{CIE}+-+\mathrm{Z} \% \mathrm{C} 3 \% \mathrm{~A} 1$ vere $\% \mathrm{C} 4 \% 8 \mathrm{D}-$ n\%C3\%A1+spr\%C3\%A1va.pdf (last accessed 24 March 2020).

Herrera, Liliana and Heijs, Joost. 2004. "The distribution of R\&D subsidies and its effect on the final outcome if innovation policy." The Druid Summer Conference 2004 od Industrial Dynamics, Innovation and Devlopment. Elsinore Denmark, June 14-16. 2004.

Hoffman, István. 2018. "Some Thoughts on the Administration of the Regional Development in the Member States of the EU: In the Light of the Role of the Municipal Bodies." Central European Public Administration 16(1), 7-29.

Hud, Martin and Katrin Hussinger. 2015. "The Impact of R\&D Subsidies during the Crisis." Research Policy 44(10), 1844-1855.

Khandker, Shahidur et al. 2009. Handbook on Impact Evaluation. London: Library Press.

Leibowicz, Benjamin D. 2018. "Welfare Improvement Windows for Innovation Policy." Research Policy 47(2), 390-398.

Lešková, Alexandra and Valéria Némethová. 2016. "Podpora vs. výsledky: Meranie dopadov regionálnej politiky Európskej únie." Regionální rozvoj mezi teorií a praxí 4, 1-12.

Mamede, Ricardo, et al. 2015. "Counterfactual Impact Evaluation of EU Funded Enterprise Support in Portugal." WP 2015/05, Dinamiacet. Available at https:// repositorio.iscte-iul.pt/bitstream/10071/10729/1/DINAMIA_WP_2015-05. pdf (last accessed 27. October 2020).

Mandl, Ulrike, Adriaan Dierx and Fabienne Ilzkovitz. 2008. "The Effectiveness and Efficiency of Public Spending." Economic Paper 301. Brussels: European Communities.

Marino, Marianna et al. 2016. "Additionality or Crowding-out? An Overall Evaluation of Public R\&D Subsidy on Private R\&D Expenditure." Research Policy 45(9), 1715-1730.

Mihau, Diana, et al. 2010. "Efficiency, Effectiveness and Performance of the Public Sector." Romanian Journal of Economic Forecasting 4(1), 132-147. 
Ministry of Economy of the Slovak Republic. 2014. Plán hodnotení Operačného programu Konkurencieschopnost' a hospodársky rast na programové obdobie 2007-2013. Ministerstvo hospodárstva SR. Available at https://www. economy.gov.sk/eu-a-fondy/eurofondy/po-2004-2006-a-2007-2013/operacny-program-konkurencieschopnost-a-hospodarsky-rast-zakladne-dokumenty/monitorovanie-a-hodnotenie/hodnotenie (last accessed 24 March 2020).

Némethová, Valéria et al. 2019. "Public Support for Firms in Lagging Regions: Evaluation of Innovation Subsidy in Slovakia." Science and Public Policy 46(2), 173-183.

Nyikos, Györgyi and Zsuzsanna Kondor. 2019. “The Hungarian Experiences with Handling Irregularities in the Use of EU Funds." NISPAcee Journal of Public Administration and Policy 12(1), 113-134.

OECD. 2019. "Innovation Indicators." Available at http://www.oecd.org/sti/inno/ innovation-indicators-2019.xlsx (last accessed 17. November 2020).

Pisár, Peter et al. 2020. "The Contribution of Innovation Actors into Business R\&D Funding: Does the Substitution Effect of Public Support Work in the EU?" E a M: Ekonomie a Management 23(1), 121-134.

Potluka, Oto and Milan Špaček. 2013. "Postupy a metody kontrafaktuálních dopadových evaluací pro Operační program Zaměstnanost $\mathrm{v}$ období 2014-2020." Omega TA ČR TS010083. Available at https://www.mpsv.cz/ documents/20142/848077/Metodika_CIE_MPSV_131015.pdf/cbe02b6d4042-6801-14a5-1f40cd597a7d (last accessed 24. January 2021).

Radicic, Dragana et al. 2016. “The Impact of Innovation Support Programs on Small and Medium Enterprises Innovation in Traditional Manufacturing Industries: An Evaluation for Seven European Union Regions." Environment and Planning C: Politics and Space 34(8), 1425-1452.

Reinkowski, Janina et al. 2011. "Do Public Subsidies Add to Private Sector R\&D Activity? Microeconomic Evidence for Regional Innovation Policy in East Germany." GERFA. Available at http://www-sre.wu.ac.at/ersa/ersaconfs/ersa10/ ERSA2010finalpaper 1071.pdf (last accessed 10. March 2021).

Šipikal, Miroslav, Peter Pisár and Viera Labudová. 2013. "Are Subsidies Really Needed? The Case of EU Regional Policy in the Czech and Slovak Republic." E a M: Ekonomie a Management 16(4), 30-41.

Šipikal, Miroslav and Valéria Szitásiová. 2020. Metódy hodnotenia programov a projektov. Bratislava: Ekonóm.

Šipikal Miroslav et al. 2017. "Evaluation of Innovation Support from EU Funds in the Manufacturing of Wood and Wood Products in the Slovak Republic." Acta Facultatis Xylologiae Zvolen 59(2), 167-180. 
Spielkamp, Alfred and Cyril Rammer. 2009. "Financing of Innovation: Thresholds and Options." Management \& Marketing 4(2), 3-18.

White, Howard. 2009. "Theory Based Impact: Evaluation: Principles and Practice." 3ie Working Papers 06(2009). Available at https:/gwbweb.wustl.edu/ Resources-and-Initiatives/Professional-Development/Documents/White3ie-2009.pdf (last accessed 4. April 2021).

Wing, Coady, Kosali Simon and Ricardo A. Bello-Gomez. 2018. "Designing Difference in Diferences Studies: Best Practices for Public Health Policy Research." Annual Review of Public Health 39, 453-469. 